\title{
COMPARISON OF THE INFLUENCE OF POLYACRYLAMIDE AND SODIUM OLEATE ON SELECTIVE FLOCULATION OF GOETHITE FROM SLUDGE
}

\author{
Lj. Tankosić1\#, S. Sredić1 \\ 1 University of Banja Luka, Faculty of Mining, Prijedor, Bosnia and Herzegovina
}

Received: June 9, 2021; Accepted: October 26, 2021

\begin{abstract}
The paper represents a part of research conducted with the aim of examining the possibility of applying selective flocculation of goethite from sludge that occurs in the process of iron ore production. The aim of this study was to compare the influence of polyacrylamide and sodium oleate as a flocculant on the settling behavior of goethite under different conditions. The paper presents the results of the research on the influence of the flocculants based on polyacrylamide and sodium oleate, as well as pH values on the settling rate of a natural goethite sample. The results showed that the settling rate of goethite was influenced by $\mathrm{pH}$ value and the type of flocculant, while the concentration of flocculant did not significantly affect the settling rate. Measurements of zeta potential showed the effect of flocculants on the surface of the goethite.
\end{abstract}

Key words: Goethite; Flocculation; Settling rate; Zeta potential.

\section{Introduction}

In recent years, generation of fines and slimes during mining and mineral processing has become an important problem, both economically and ecologically. The large quantity of these fines/slimes are often discarded as waste into tailing ponds. In the mineral processing, many of wastes contain colloidally stable dispersions. These are, as a rule, complex systems, which contain several mineral species. Fine iron ores most often contain clay, silica, and other minerals as gangue material along with iron minerals. For these reasons, a number of new approaches to recover the fine and ultrafine particles have been investigated, including selective flocculation.

Processing of iron ore in Omarska mine is carried out by following methods: washing, sieving, grading, and magnetic concentration. The large quantity of fine sized $(<15 \mu \mathrm{m})$ sludge disposed as final waste in the beneficiation plants of the Omarska mine (Republic of Srpska, Bosnia and Herzegovina) is an important economically and ecologically problem. The sludge samples are mostly composed of goethite- $\mathrm{FeO}(\mathrm{OH})$ and quartz, less clay minerals (mostly illite-sericite), and the least part is formed of magnetite and todorokite [1, 2].

One of the most investigated techniques for removing of gangue from fine iron ores is selective flocculation [2-11]. Generally, flocculation is the process in which fine particles, dispersed in water or other liquid, aggregate under the influence of binding compounds called flocculants [12]. A flocculant molecule bind particles into aggregates, after adsorption of different parts of a flocculant chain simultaneously on several particles. Newly formed aggregates of fine particles, called flocs, have considerably larger size than initial particles, so due to gravity forces, they settle much faster than single particles [2]. Selective separation of mineral components is achieved in flocculation process by addition of specific flocculants with/without dispersants and manipulation of solution conditions ( $\mathrm{pH}$, solid /liquid ratio, a flocculant dose) to produce different surface properties for mineral components. The flocculation behaviour of mineral components depends on the surface properties. Selective flocculation studies of iron ore were carried out using different flocculants, such as starch [13-17], polyacrylamide [18-22], oleate [23-27], etc., but mostly on hematite. The characteristics of ores/slimes from different localities differ substantially and the knowledge about fine goethite ore processing is still relatively poor [28-30].

The reason for this research is that the selectivity of anionic polyacrylamide has not been achieved in the flocculation of waste sludge from the Omarska mine. 
These results suggest that it is necessary to further examine the individual components and their behavior in a complex system such as sludge, in order to determine the best parameters (conditions, reagents, etc.) for selective flocculation $[2,32,33]$.

This paper presents a part of research of individual components of waste sludge from the Omarska mine. The polyacrylamide and sodium oleate efficiency in goethite removal from aqueous solutions was investigated on a sample of natural goethite from Omarska mine. In order to compare of the two flocculants, a study of the flocculation goethite suspensions using anionic polyacrylamide and sodium oleate as flocculants was made by determining the settling rates of the suspensions and the amount of suspended solids. All experiments were performed as a function of the $\mathrm{pH}$ value and flocculant dosage.

\section{Materials and Methods}

\subsection{Materials}

\subsubsection{Goethite}

Representative iron ore from Omarska mine, labeled as "limonite ore" was handpicked. The "limonite ore" samples are mostly composed of goethite - $\mathrm{FeO}(\mathrm{OH})$ which dominate over hematite $\left(\mathrm{Fe}_{2} \mathrm{O}_{3}\right)$, and with minor contents of magnetite $\left(\mathrm{Fe}_{3} \mathrm{O}_{4}\right)$, quartz $\left(\mathrm{SiO}_{2}\right)$ and clay minerals. The XRPD, FTIR, and SEM-EDS analyses were recently performed for obtaining more precise mineral determination [31-33]. The density of the sample was also determined: $3.940 \mathrm{~g} / \mathrm{cm}^{3}$. Chemical composition obtained by wet analysis of natural goethite from Omarska mine is given in Table 1 and typical SEM image and chemical composition obtained by $\mathrm{X}$-ray microanalysis (EDS) from selected point is given in Figure 1.

Table 1 Chemical composition of the goethite from Omarska mine

\begin{tabular}{lcccccc}
\hline \multirow{2}{*}{ Sample } & \multicolumn{6}{c}{ Chemical compositions (in mass \%) } \\
\cline { 2 - 7 } & $\mathrm{Fe}$ & $\mathrm{SiO}_{2}$ & $\mathrm{Al}_{2} \mathrm{O}_{3}$ & $\mathrm{CaO}$ & $\mathrm{MgO}$ & $\mathrm{TiO}_{2}$ \\
\hline Goethite & 57.16 & 4.44 & 0.59 & 0.03 & 0.22 & $<0.01$ \\
\hline \multirow{2}{*}{ Sample } & \multicolumn{6}{c}{ Chemical compositions (in mass $\%$ ) } \\
\cline { 2 - 7 } & $\mathrm{P}$ & $\mathrm{Mn}$ & $\mathrm{S}$ & $\mathrm{Na}_{2} \mathrm{O}$ & $\mathrm{K}_{2} \mathrm{O}$ & $\mathrm{LOI}$ \\
\hline Goethite & 0.078 & 1.18 & 0.007 & 0.009 & 0.033 & 10.86 \\
\hline
\end{tabular}

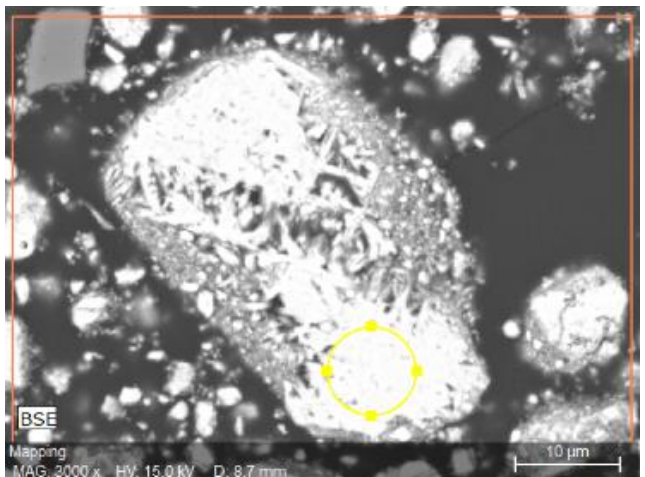

(a)

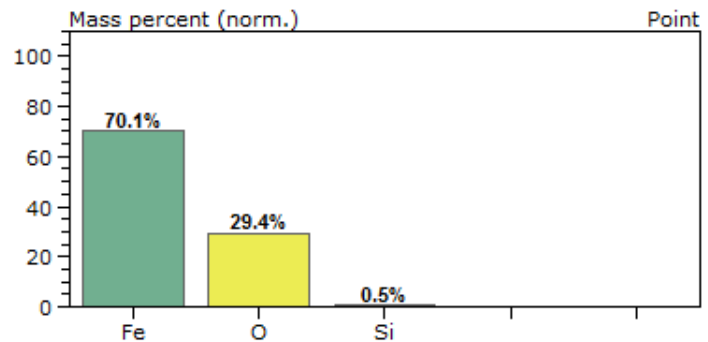

(b)

Figure $1 \mathrm{SEM}$ image of goethite ore from Omarska mine (a) with EDS data of selected point (b)

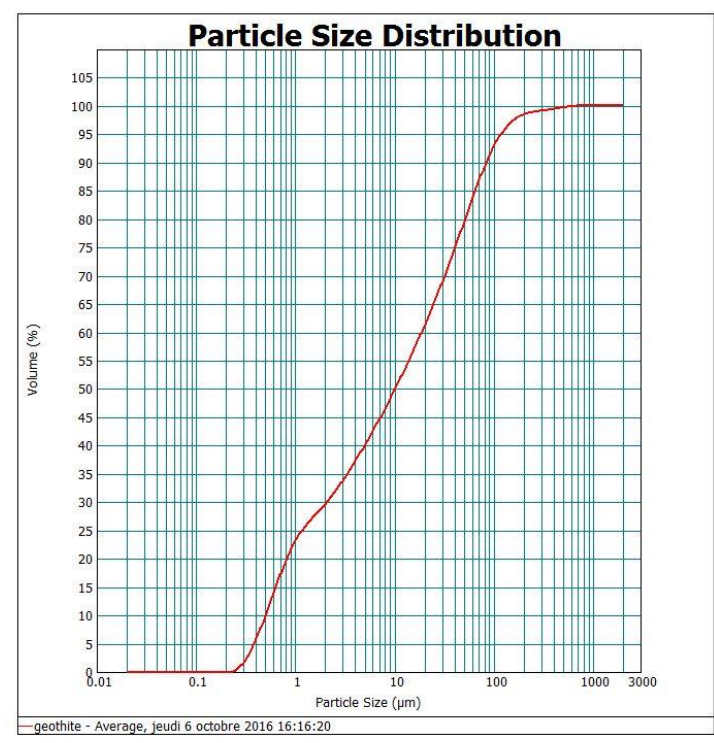

Figure 2 Particle size distribution of goethite

The result of particle size distribution analyzes of the goethite sample is given in Figure 2. It is clearly seen that: $80 \%$ was below $50 \mu \mathrm{m}, 65 \%$ was below $25 \mu \mathrm{m}$ and the highest mass percentage (about 50\%) belonged to 
the finest classes, i.e. to those bellow $10 \mu \mathrm{m}$. This confirmed that the limonite ore from Omarska was finegrained, which was one of the reasons for the large amount of waste sludge.

\subsubsection{Flocculants}

This work is a continuation of previous research, so the same reagents were used and the experimental procedure was the same, as previously described [2].

Polyacrylamide and its derivative are widely used as thickening agent, super absorbent, soil conditioner, flocculating agent, suspending agent, etc. There are three types of PAM, cationic, nonionic, and anionic (Figure 3). Flocculation with high molecular weight polymers was formed by the association of particles due to the adsorption of molecules or micelles of polymers (flocculants) which with their hydrocarbon radicals form, as already mentioned, "bridged" between particles [12]

$$
\begin{aligned}
& \left(\mathrm{CH}_{2}-\mathrm{NH}_{\mathrm{N}}^{\mathrm{NH}}\right)_{\text {Anionic PAA }}\left(\mathrm{CH}_{2}-\mathrm{O}_{\mathrm{n}}^{-} \mathrm{Na}^{+}\right. \\
& \left(\mathrm{CH}_{2}-\underset{\mathrm{O}=}{\mathrm{C}} \mathrm{H}\right)_{\mathrm{m}} \\
& \left(-\mathrm{CH}_{2}-\underset{\mathrm{NH}}{\mathrm{CH}}\right)_{\mathrm{m}}^{\text {Nonionic PAA }}\left(\mathrm{CH}_{2}-\underset{\mathrm{C}}{\mathrm{CH}}\right)_{\mathrm{n}}
\end{aligned}
$$

Figure 3 Polyacrylamide structure

Sodium oleate (cis-9-octadecenoic acid salt) is already a well-known collector in flotation of iron ore, especially hematite. Also, the use of sodium oleate as a flocculant is known in the literature. Oleate can act as a flocculant over a wide $\mathrm{pH}$ range depending on its concentration [25-26].

$$
\mathrm{CH}_{3}\left(\mathrm{CH}_{2}\right)_{6} \mathrm{CH}_{2}=\mathrm{CH}_{2}\left(\mathrm{CH}_{2}\right)_{5} \mathrm{CH}_{2} \stackrel{\mathrm{ONa}}{=}
$$

Figure 4 Structure of sodium oleate

\subsection{Methods}

\subsubsection{Settling and flocculation studies}

The natural settling, and settling with the addition of sodium oleate (SO) and polyacrylamide (PAM) as flocculant, were determined. The flocculation experiments were performed at a pulp density with $13.8 \%$ of solid, which was adequate to the simulation of natural industrial conditions. To examine the effect of flocculant dosage the following were used: (i) Beaker of $100 \mathrm{ml}$ volume, (ii) $13.8 \mathrm{~g}$ of dry sample in $100 \mathrm{ml}$ of distilled water for the experiment; (iii) $250 \mathrm{~g} / \mathrm{t}, 500 \mathrm{~g} / \mathrm{t}$, $1000 \mathrm{~g} / \mathrm{t}$ of sodium oleate (SO), and (iv) $50 \mathrm{~g} / \mathrm{t}, 100 \mathrm{~g} / \mathrm{t}$, $250 \mathrm{~g} / \mathrm{t}$ of PAM. To compare the efficacy of two flocculants the following were used: (i) Beaker of $100 \mathrm{ml}$ volume, (ii) $13.8 \mathrm{~g}$ of dry sample in $100 \mathrm{ml}$ of distilled water for the experiment; and (iii) $250 \mathrm{~g} / \mathrm{t}$ of SO and 250 $\mathrm{g} / \mathrm{t}$ of PAM. All of the tests were performed at the $\mathrm{pH}=4$, $\mathrm{pH}=7$, and $\mathrm{pH}=10.5$. For flocculation tests, the sample was mixed for two minutes. After adjusting $\mathrm{pH}$ value, the suspension continued to mix for two minutes. After addition of flocculant, sample was mixed for five minutes, and left to settle for one minute, separated float from sink, dried both of them at $105^{\circ} \mathrm{C}$ in oven and weighed the sediment material [2, 32, 33].

\subsubsection{Zeta Potential Measurements}

The electrokinetic (zeta) potential of minerals was determined by electrophoresis, by measuring the electrophoretic mobility of mineral particles with a Malvern Zetasizer Nano Z device. The Zetasizer Nano Z system is intended for measuring zeta potential and electrophoretic mobility in aqueous and organic dispersions using the laser effect of Doppler microelectrophoresis. Laser wavelength was $633 \mathrm{~nm}$. Preparation of minerals for testing was performed under the following constant conditions:

- Mass of the mineral sample in each individual experiment $0.010 \mathrm{~g}$, and

- Volume of solution in which conditioning was performed $100 \mathrm{ml}$.

\section{Results and discussion}

\subsection{Settling and flocculation studies}

In solid-liquid systems, the settling velocity of the solids depend on size and shape of the grain, the fluid 
and grain density, charge density, etc. The highest mass percentage (about $50 \%$ ) of investigated sample belonged to the finest classes, i.e. to those below 10 $\mu \mathrm{m}$. As expected, decreasing a particle's size reduced its settling rate. For that reason, it is necessary to produce more rapid settling of fine particles by using flocculation technique.

The main goal of settling and flocculation studies was to compare the behavior of natural goethite samples with or without two different flocculants (anionic polyacrylamide A100 and sodium oleate, SO). These experiments aimed to demonstrate the possible impact of different input flocculants on the behavior of settling rate on different $\mathrm{pH}$ value.

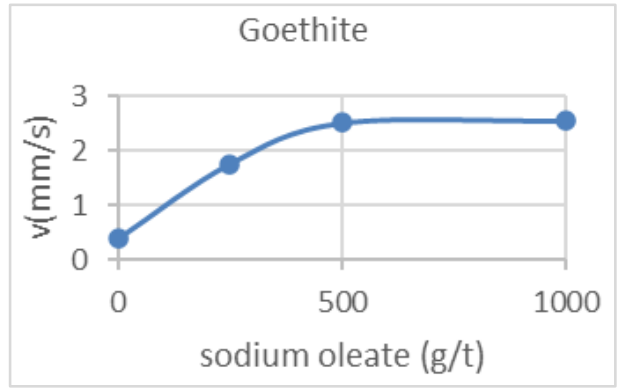

(a)

\subsubsection{Influence of the type and dosage of flocculants on settling rates}

The effect of two flocculants was studied by comparing critical rates. The critical rate (Vav) in this paper was calculated in the same way as we described in a previous paper [2].

The usual doses for each flocculant were used, taking into account the maximum doses recommended for each of them. The effect of different flocculants was studied by conducting settling tests at $\mathrm{pH} 7$, which was an average $\mathrm{pH}$ value in real conditions.

Settling rates of the goethite suspensions depending on the dosage of two different flocculants are shown in Figure 5 (a) and (b) and Figure 6.

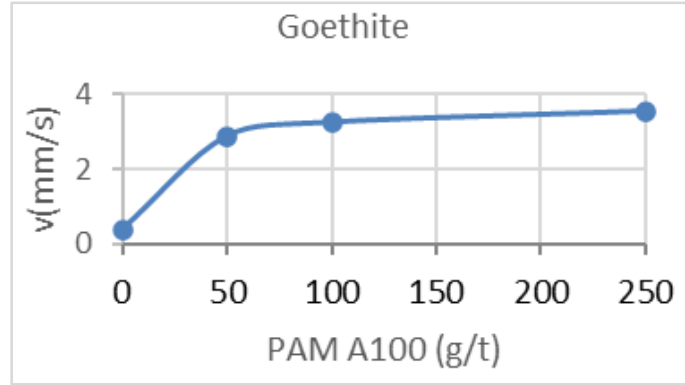

(b)

Figure 5 Settling rates of the goethite suspensions depending on the amount added flocculant: sodium-oleate (a) and PAM A100 (b)

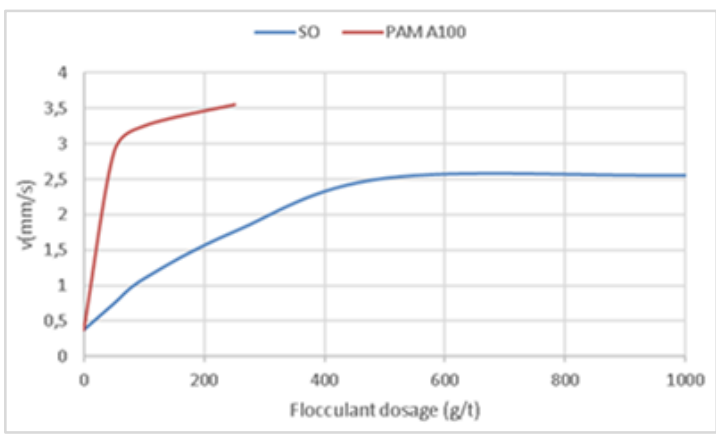

Figure 6 Settling rates of the goethite suspensions for two flocculants comparatively

\subsubsection{Influence of $\mathrm{pH}$}

Generally, the stability of the metal oxide suspension strongly depends on the $\mathrm{pH}$ value, because their surface charge becomes increasingly positive as the $\mathrm{pH}$ decreases and becomes increasingly negative as the $\mathrm{pH}$ increases. The charge on most oxides in aqueous systems is controlled by the acid-base chemistry of surface oxide and hydroxide species. The stability of the goethite suspension without flocculants strongly depends on the $\mathrm{pH}$ value. This is clearly seen in Figure 7 in which shows natural settling curves of goethite at different $\mathrm{pH}$ values. There was no settling at either $\mathrm{pH} 4$ or $\mathrm{pH} 10$, because the increase of surface charge caused the repulsive forces.

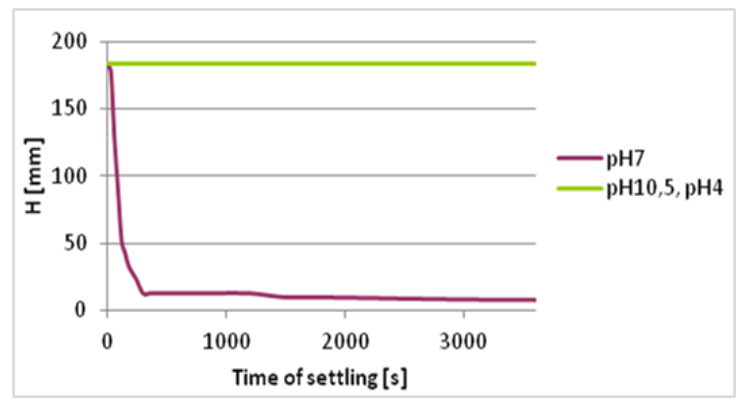

Figure 7 Natural settling of goethite at different $\mathrm{pH}$ values [32] 
Influence of the type of flocculants on settling behavior of goethite depending on $\mathrm{pH}$ was also investigated. As an illustration, Figure 8 shows settling experiments with goethite in the presence of anionic polyacrylamide $\mathrm{A} 100$ at different $\mathrm{pH}$ values.

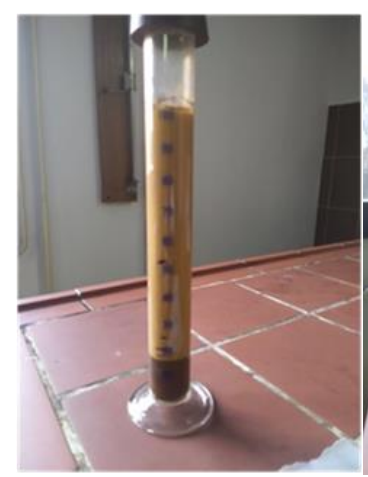

(a)

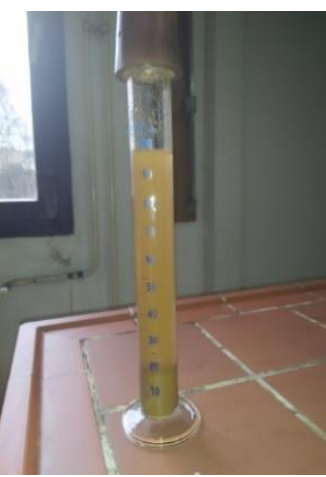

(b)

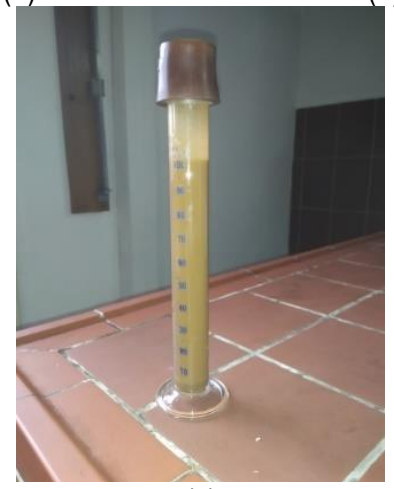

(c)

Figure 8 Illustration of Goethite + PAM A100 settling at: $\mathrm{pH}=4$ (a); $\mathrm{pH}=7$ (b); (c) $\mathrm{pH}=10.5$

Setlling tests of goethite with different flocculants and different $\mathrm{pH}$ showed that it was not possible to monitor the deposition because the column of sediment was turbid, i.e. no clear deposition could be seen. At pH value of 7 , it was possible to determine the settling time because the water column was clearer and the settling was visible.

The effect of flocculants was also highly dependent on $\mathrm{pH}$ (Figure 8 - 9), but there was no difference in the behavior of the suspension, regardless of used flocculant. Since in both cases the settling occurred very quickly (within 60 seconds) at $\mathrm{pH}=7$, a slight difference between the action of the two flocculants was seen in this interval (Figure 10). Settling tests with additional different flocculants at different $\mathrm{pH}$ showed that none of the sample was precipitated at $\mathrm{pH}=4$ and $\mathrm{pH}=10.5$.

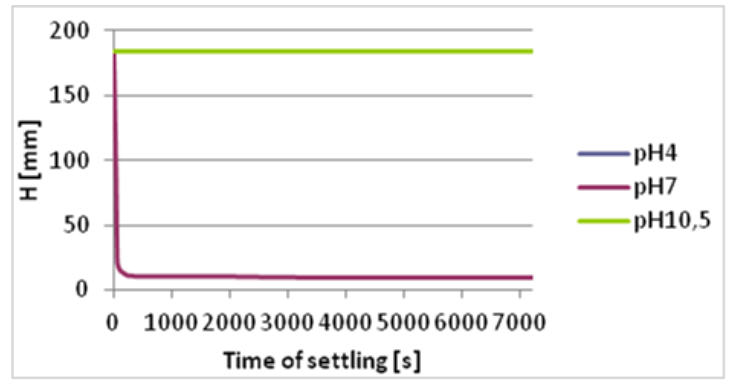

(a)

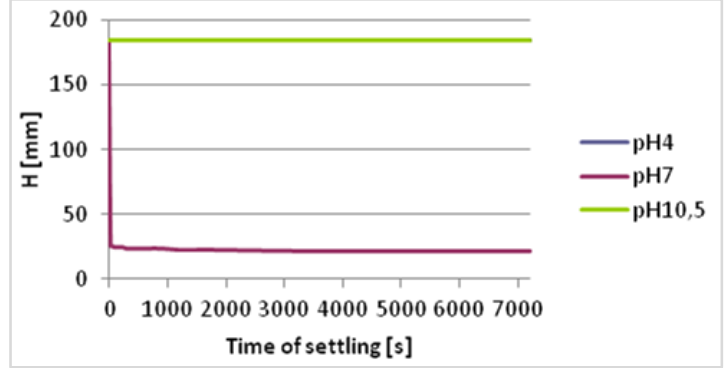

(b)

Figure 9 Flocculation settling of goethite at different $\mathrm{pH}$ values: (a) with sodium-oleate; (b) with PAM A100

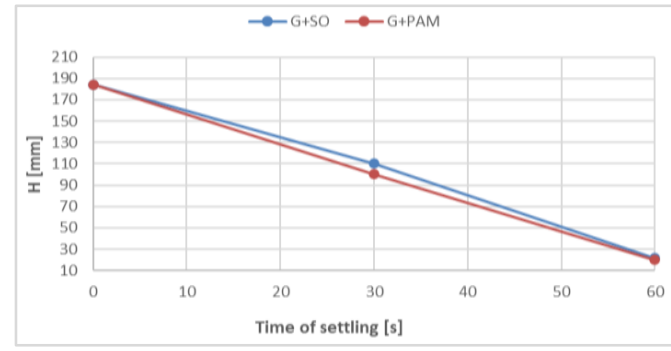

Figure 10 Flocculation settling of goethite at $\mathrm{pH} 7$ for two flocculants comparatively

Since the positive charge of the goethite decreased with increasing the $\mathrm{pH}$ value, the occurrence of inefficient action of both flocculants in an alkaline medium was understandable. From the other side dependence of flocculation on $\mathrm{pH}$ could be due to the effect of $\mathrm{pH}$ on the surface characteristics of goethite in water as well as that on the anionic polyacrylamide and sodium oleate solution chemistry. Namely, for anionic polyacrylamide and sodium oleate, in the base medium, anionic spices were predominate as well as for goethite. The settling in a neutral medium occurred because in the neutral pH (range of about 5-8) neutral surfaces predominated, both in goethite and in both flocculants (the un-dissociated oleic acid and weakly dissociated polyacrylamide). 
A comparison of the amounts of suspended solids as a function of $\mathrm{pH}$ showed that the highest amounts were expected at $\mathrm{pH}=7$ in both cases regardless of the dosage of flocculants (Figure 11-12).

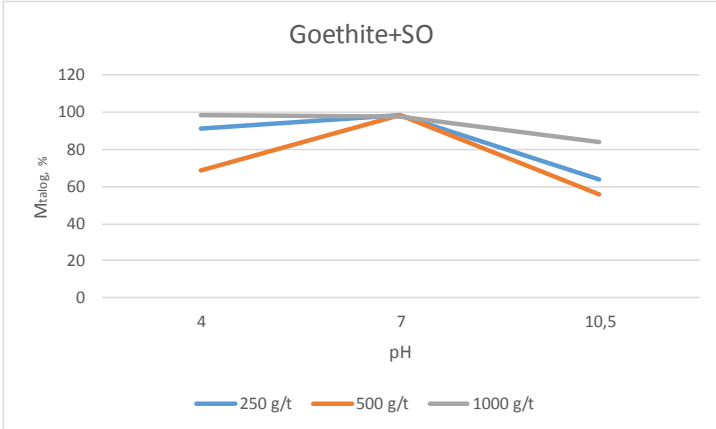

(a)

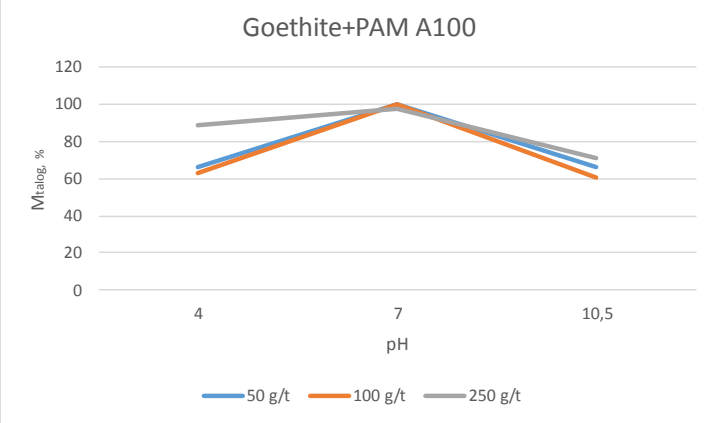

(b)

Figure 11 Amount of suspended solids with different dosage of: sodium oleate (a); PAM (b)

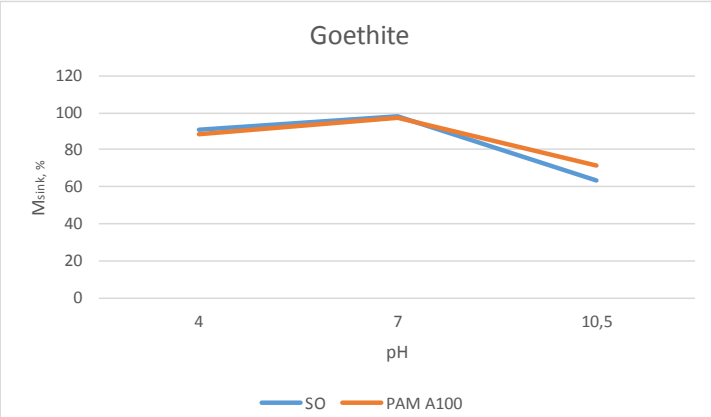

Figure 12 Amount of suspended solids with dosage of $250 \mathrm{~g} / \mathrm{t}$ with sodium oleate and PAM A100 comparatively

\subsection{Zeta potential study}

The zeta potential of the goethite samples in presence/absence of two different flocculants is shown in Figure 13.

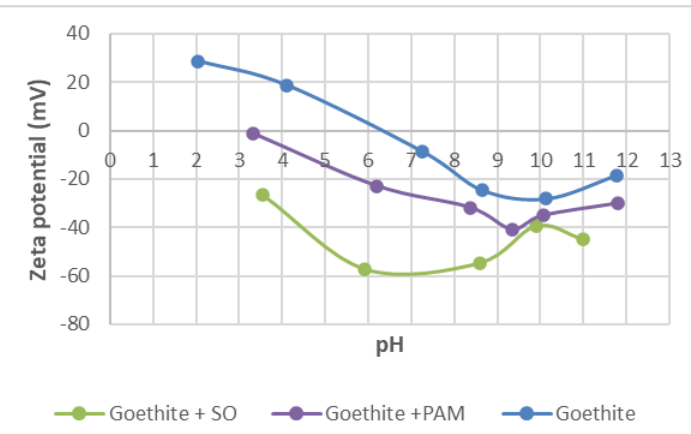

Figure 13 Zeta potential of the goethite samples in presence/absence of different flocculants

The electro kinetic (zeta, $\zeta$ ) potential of minerals is a potential at the hydrodynamic shear plane of the double electric layer mineral/solution. As a measure of the magnitude of the charge repulsion/attraction between particles, it is one of the most important parameters known to affect flocculation behavior. Isoelectric point (IEP) represents condition when value of zeta potential is zero. As a rule, $\pm 30 \mathrm{mV}$ is taken as the limit value of the zeta potential required for dispersion stability. Namely, at that condition, the electrostatic repulsion between particles is typically strong enough to prevent particles attraction.

Zeta-potential curves for natural mineral raw sample of goethite was previously determined [2,32] and the IEP for natural goethite was observed at $\mathrm{pH}=6.6$. The magnitude of the positive zeta potential goethite was maximized at $\mathrm{pH}=2$ value, and the magnitude of the negative zeta potential was maximized at $\mathrm{pH}=10$ value. That corresponded with settling behavior of goethite (Figure 7), because a higher zeta potential produced a stable dispersion. At $\mathrm{pH} 7$ fast settling of goethite particles occurred. After interacting with flocculants, the changes in zeta potential of goethite surface were obvious, indicating that the both flocculants did interact with the goethite surface causing an increase of negative zeta potential magnitudes in both of the investigated cases, as it can be seen from Figure 13. Also, it can be seen that the surface charge remained negative throughout all of the investigated $\mathrm{pH}$ values, after addition flocculants. The difference of the zeta potentials of goethite after interaction with used flocculants indicated a more pronounced flocculation for goethite with PAM than for goethite with sodium oleate. That corresponded with settling rate comparison shown in Figure 6, where a significantly greater effect of PAM on the settling rate of goethite could be seen. 


\section{Conclusion}

The anionic polyacrylamide and sodium oleate efficiency in goethite removal from aqueous solutions was investigated on a sample of natural goethite from Omarska mine.

Comparison of the critical settling rates showed that the addition of the flocculant increased critical rates in both cases, but more significant in the case of using PAM A100.

The natural settling behavior of the goethite without flocculant strongly depended on the $\mathrm{pH}$ value, because their surface charge in aqueous systems was controlled by the acid-base chemistry of surface oxide and hydroxide species. There was not settling at either $\mathrm{pH}=4$ or $\mathrm{pH}=10$, because the increase of surface charge caused the repulsive forces.

The settling behavior of the goethite with additional flocculant was influenced more by the type of flocculants and $\mathrm{pH}$ value, than by the dosage of the flocculant.

The effect of anionic polyacrylamide and oleate as a flocculants was highly dependent on $\mathrm{pH}$. This was expected because the species distribution of sodium oleate and the charge density of ionic polymers also depended on the $\mathrm{pH}$ conditions. Effect of anionic polyacrylamide and sodium oleate on the flocculation of goethite was noticeable at $\mathrm{pH}=7$ only. A comparison of the amounts of suspended solids as a function of $\mathrm{pH}$ showed that the highest amounts were expected at $\mathrm{pH}=7$ in both cases regardless of the dosage of flocculants.

After interacting with flocculants, the changes in zeta potential of goethite surface were obvious, indicating that the both flocculants did interact with the goethite surface causing an increase of negative zeta potential magnitudes in both of the investigated cases. The difference of the zeta potentials of goethite after interaction with used flocculants indicated a more pronounced flocculation for goethite with PAM than for goethite with sodium oleate.

The highest settling rate of goethite and the highest amount of suspended solids were achieved under the following conditions: at $\mathrm{pH}=7$ and the addition of anionic polyacrylamide with dosage of $250 \mathrm{~g} / \mathrm{t}$.

In relation to selectivity, our unpublished results indicate greater selectivity of oleates, but the conclusion can be made only when all research with anionic polyacrylamide on other components of sludge (quartz and clay sample from Omarska mine) is completed.

\section{Note}

A part of this study was presented at the XIV International Mineral Processing and Recycling Conference, organized by the University of Belgrade, Technical Faculty in Bor, from $12^{\text {th }}$ to $14^{\text {th }}$ May 2021, Belgrade, Serbia.

\section{Acknowledgments}

The authors are also grateful to the ArcelorMittal company in Prijedor (Bosnia and Herzegovina) for technical support and enabling the study visit of L.T. to the laboratory Global Research and Development, Mining and Mineral Processing, Maizières-lès-Metz (France), for the purpose of preparation of her PhD; to Armando Araujo for the zeta potential measurements with polyacrylamide at Universidad Federal de Minas Gerais, Belo Horizonte (Brazil).

The authors want also to offer their gratitude to the Institute for Technology of Nuclear and Other Mineral Raw Materials, for providing zeta potential measurements with sodium oleate.

\section{References}

[1] Tankosić, Lj., Tančić, P., Sredić, S., Nedić, Z. (2017) Characterization of the sludge generated during the processing of iron ore in Omarska mine. In: 6th International Symposium "Mining and Environmental Protection" 21th-24th June 2017. Vrdnik, Serbia, Proceedings, 255-262.

[2] Tankosić, Lj., Tančić, P., Sredić, S., Nedić, Z. (2018) Comparative Study of the Mineral Composition and Its Connection with Some Properties Important for the Sludge Flocculation Process - Examples from Omarska Mine, Minerals 8, 119.

[3] Qi, C., Fourie, A. (2019) Cemented paste backfill for mineral tailings management: Review and future perspectives. Minerals Engineering, 144, [106025]. https://doi.org/10.1016/j.mineng.2019.106025

[4] Kumar, R., Mandre, N.R. (2017) Recovery of iron from iron ore slimes by selective flocculation. J. S. Afr. Inst.Min. Metall., 117, 397-400.

[5] Su, T., Chen, T., Zhang, Y., Hu, P. Selective Flocculation Enhanced Magnetic Separation of Ultrafine Disseminated Magnetite Ores. Minerals, 6, 86, 1-12. 
[6] Ahmed, H.A.M., Mahran, G.M.A. (2013) Processing of Iron Ore Fines from Alswaween Kingdom of Saudi Arabia. Physicochem. Probl. Miner. Process. 49, 419-430.

[7] Panda, L., Biswal, S.K., Tathavadkar, V. (2010) Beneficiation of Synthetic Iron Ore Kaolinite Mixture Using Selective Flocculation. J. Miner. Mater. Charact. Eng., 9, 973-983.

[8] Ajaka, E.O. (2009) Recovering Fine Iron Minerals from Itakpe Iron Ore Process Tailing. J. Eng. Appl. Sci., 4, 17-28.

[9] Somasundaran, P., Runkana, V. (2000) Selective flocculation of fines. Trans. Nonferrous Met. Soc.China 10, 8-11.

[10] Sresty, G.C., Somasundaran, P. (1980) Selective Flocculation of Synthetic Mineral Mixtures Using Modified Polymers. Int. J. Miner. Process. 6, 303-320.

[11] Weissenborn, P.K., Warren, L.J., Dunn, J.G. (1994) Optimisation of selective flocculation of ultrafine iron ore. Int. J. Miner. Process., 42, 191-213.

[12] Drzymala, J. (2007) Mineral Processing, 1st edition, Foundations of Theory and Practice of Minerallurgy; Wroclaw University of Technology: Wrocław, Poland, pp. 449-462.

[13] Lima, R.M., Abreu, F.V., (2020) Characterization and concentration by selective flocculation /magnetic separation of iron ore slimes from a dam of Quadrilátero Ferrífero Brazil, J. mater. res. Technl., 9 (2), 2021-2027.

[14] Severov, V.V., Filippova, I.V. (2013) Mechanism of starch adsorption on Fe-Mg-Al-bearing amphiboles, International Journal of Mineral Processing 123, 120-128.

[15] Panda, L., Banerjee, P.K., Biswal, S.K., Venugopal, R, Mandre, N.R. (2013) Performance evaluation for selectivity of the flocculant on hematite in selective flocculation, International Journal of Minerals, Metallurgy and Materials, 20 (12), 11-23.

[16] Abro, M.I., Pathan, A.G., Memon, A.R., Sirajuddin. (2013) Dual polymer flocculation approach to overcome activation of gangue minerals during beneficiation of complex iron ore, Powder Technology, 245, 281-291.

[17] Ma, M. (2012) The significance of dosing sequence in the flocculation of hematite. Chemical Engineering Science, 73. 51-54.

[18] Yue, T., Wu, X., Chen, X., Liu, T.A. (2018) Study on the Flocculation and Sedimentation of Iron Tailings
Slurry Based on the Regulating Behavior of Fe3+. Minerals, 8, 421.

[19] Orumwense, F.F.O., Nwachukwu, J.C. (2000) Flocculation studies on hematite-silica system using polymeric flocculants. Indian J. Chem. Technol. 7 , 23-29.

[20] Khangaonkar, P.R., Bala Subramani, K.J. (1993) Flocculation of hematite fines by anionic polyacrylamide polymers, Minerals Engineering, 6 (7), 765-774.

[21] Ravishankar, S.A., Pradip, Khosla, N.K. (1995) Selective flocculation of iron oxide from its synthetic mixtures with clays: a comparison of polyacrylic acid and starch polymers, International J. of Mineral Processing, 43 (3-4), 235-247.

[22] Jin, R., Hu, W., Hou, X. (1987) Mechanism of selective flocculation of hematite from quartz with Hydrolysed polyacrilamyde. Colloids Surf. 26, 317-331.

[23] Roth, HC., Schwaminger, S., Fraga García, P. et al. (2016) Oleate coating of iron oxide nanoparticles in aqueous systems: the role of temperature and surfactant concentration. J Nanopart Res. 18 (4), 1-12.

[24] Yin, W., Yang, X., Zhou, D., Li, Y., Lü, Z. (2011) Shear hydrophobic flocculation and flotation of ultrafine Anshan hematite using sodium oleate, Transactions of Nonferrous Metals Society of China, 21 (3), 652-664.

[25] Shibata, J., Fuerstenau, D.W. (2003) Flocculation and flotation characteristics of fine hematite with sodium oleate, International J. of Mineral Processing, 72 (1-4), 25-32.

[26] Pascoe, R.D., Doherty, E. (1997) Shear flocculation and flotation of hematite using sodium oleate, International J. of Mineral Processing, 51 (1-4), 269-282.

[27] Morgan, L.J., Somasundaran, P., Partyka, S. (1987) Adsorption of Hydrolyzable Surfactants: Effect of Precipitation on Adsorption of Oleate on Hematite, Colloids and Surfaces, 2 (7) 15-27.

[28] Sadangi, J.K., Sahoo, A.K., Sushobhan, B.R., et al. (2020) Effect of anionic flocculant on settling rate of iron ore ultra-fines, Materials Today Proceedings, 30 (2), 316-321.

[29] Szewczuk-Karpisz, K., Krasucka, P., Boguta, P. et al. (2019) Anionic polyacrylamide efficiency in goethite removal from aqueous solutions: goethite suspension destabilization by PAM, Int. J. Environ. 
Sci. Technol., 16, 3145-3154.

[30] Tankosić, Lj., Calic, N., Kostović, M. (2015) Selective flocculation of limonite and clay by polyacrylamides. In: XVI Balkan mineral processing congress, Belgrade, Serbia, Proceedings, 1109-1113.

[31] Tankosić, Lj., Tančić, P., Sredić, S., Nedić, Z., Malbašić, V. (2017) Characterization of natural raw materials in the processing of iron ore from Omarska mine. In: I International Symposium
"Mining and Geology Today", Belgrade, Serbia, Proceedings 316-330.

[32] Sredić, S., Tankosić, Lj., (2021) Effect of $\mathrm{pH}$ conditions on goethite behavior in the presence/absence of different dispersants. Contemporary Materials, XII-1, 91-98.

[33] Tankosić, Lj., et al.(2019) The dispersion flocculation behaviour of the natural raw clay samples from Omarska mine. Contemporary Materials, $\mathrm{X}-1$, 71-81.

\title{
POREĐENJE UTICAJA POLIAKRILAMIDA I NATRIJUM-OLEATA NA SELEKTIVNU FLOKULACIJU GETITA IZ TALOGA
}

\author{
Lj. Tankosić1\#, S. Sredić1 \\ 1 University of Banja Luka, Faculty of Mining, Prijedor, Bosnia and Herzegovina
}

Primljen: 9. jun 2021.; Prihvaćen: 26. oktobar 2021.

\begin{abstract}
Izvod
Ovaj rad predstavlja deo istraživanja sprovedenog sa ciljem da se ispita mogućnost primene selektivne flokulacije getita iz taloga koji nastaje tokom procesa proizvodnje rude gvožđa. Cilj istraživanja je bio da se uporedi uticaj poliakrilamida i natrijumoleata, koji su korišćeni kao flokulanti, na taloženje getita pod različitim uslovima. U radu su prikazani rezultati istraživanja uticaja flokulanata na bazi poliakrilamida i natrijum-oleata, kao i pH vrednosti za brzinu taloženja prirodnog uzorka getita. Rezultati su pokazali da na brzinu taloženja getita utiču pH vrednost i vrsta flokulanta, dok koncentracija flokulanta nije imala značajan uticaj na brzinu taloženja. Merenje zeta potencijala je pokazalo da postoji dejstvo flokulanta na površini getita.
\end{abstract}

Ključne reči: Getit; Flokulant; Brzina taloženja; Zeta potencijal. 